\title{
Investigation of genetic polymorphism of Avena sativa varieties and Avena sterilis samples using SSR-markers
}

\author{
N.I. Drobot \\ Institute of Genetics and Cytology NASB, Minsk, Belarus \\ e-mail:n.drobot@igc.by
}

Key words: Avena sativa, Avena sterilis, SSR-marker, PIC, MI

Motivation and Aim: Hexaploid oat (Avena sativa) is a valuable cereal crop worldwide. The main directions of modern oats breeding are improvement of grain quality and resistance to biotic and abiotic environmental factors, among which the most significant are insects and diseases. The most effective way to control plant diseases is to create resistant plant varieties. Wild-growing hexaploid species that have a genomic structure similar to Avena sativa L. (AACCDD), which guarantees the production of fertile hybrid forms in crosses are of a particular interest for breeding.

Methods and Algorithms: The material for this study was 15 varieties of Avena sativa L. (Fax, Myrt, Debut, Freestyle, Lydia, Zapavet, Stramec, Zolak, Ivory, Bingo, Stoper, Sprinter, Gagubatori kh, AC Goslin, AC Fracis), 12 samples of Avena sterilis L., and four highly productive hybrids. Genomic DNA purification was carried out from green leaves using the Plant DNA Preparation Kit (Jena Bioscience). The genetic polymorphism was determined using a set of 8 SSR-markers: $A M 1, A M 3, A M 4, A M 5, A M 7, A M 15, A M 22$, AM83 with standard fragment analysis (ABI 3500).

Results: As a result, 54 alleles were detected in 8 SSR-loci. The number of alleles ranged from 2 to 10, and an average amount was 6.75 per locus. The frequency of occurrence of alleles in the analyzed sample ranged from 0.06 to 0.8 . At the same time, the informative index (PIC) was from 0.2 (AM5) to 0.89 (AM3), the marker index (MI) - from 0.01 to 1.6 (Table).

Characteristics of the SSR-markers

\begin{tabular}{lllllll}
\hline $\begin{array}{l}\text { SSR- } \\
\text { marker }\end{array}$ & $\begin{array}{l}\text { Alleles } \\
\text { number }\end{array}$ & $\begin{array}{l}\text { Obtained } \\
\text { size, b.p. }\end{array}$ & $\begin{array}{l}\text { Expected } \\
\text { size, b.p. }\end{array}$ & $\begin{array}{l}\text { Frequency } \\
\text { of occurrence }\end{array}$ & $\begin{array}{l}\text { PIC } \\
\text { (pol.inf. } \\
\text { content) }\end{array}$ & $\begin{array}{l}\text { MI } \\
\text { (marker } \\
\text { index) }\end{array}$ \\
\hline AM1 & 9 & $152-213$ & $157-225$ & $0.07-0.25$ & 0.88 & 1.31 \\
\hline AM3 & 9 & $257-316$ & $243-325$ & $0.06-0.1$ & 0.89 & 1.32 \\
\hline AM4 & 7 & $129-150$ & $133-227$ & $0.08-0.21$ & 0.83 & 0.75 \\
\hline AM5 & 2 & $131-134$ & 172 & $0.1-0.8$ & 0.2 & 0.01 \\
\hline AM15 & 10 & $149-191$ & $155-198$ & $0.06-0.23$ & 0.87 & 1.6 \\
\hline AM22 & 8 & $223-229$ & 229 & $0.1-0.6$ & 0.57 & 0.17 \\
\hline AM83 & 4 & $168-304$ & 138 & $0.14-0.2$ & 0.82 & 0.97 \\
\hline
\end{tabular}

Conclusion: The highest level of polymorphism was observed for loci AM7, AM3, AM1 and AM22 (PIC - 0.87; PIC - 0.89; PIC - 0.88; PIC -0.82 respectively). At the same time loci AM5 and AM15 were characterized by low polymorphism (PIC is 0.2 and 0.57 , respectively) and the minimum number of alleles, that makes their using for studying genetic diversity inexpedient.

Acknowledgements: Supported by project 2.08 GPNI "Biotechnology". 